\title{
各種ケーソン式防波堤の反射・伝達率特性 PROPERTIES OF THE REFLECTION AND TRANSMISSION COEFFICIENT FOR SEVERAL TYPES OF BREAKWATERS
}

\author{
本田秀樹 1 ・塩崎禎郎 1 ・堀内 博 2 \\ Hideki HONDA, Yoshio SHIOZAKI and Hiroshi HORIUCHI \\ 1正会員 工修 NKK 基盤技術研究所 都市工学研究部（テ210-0855 神奈川県川崎市川崎区南渡田1-1） \\ 2正会員 工修 NKK 鉄構建設部 港湾技術室（干230-8611 神奈川県横浜市鶴見区末広町2-1）
}

\begin{abstract}
Recently, it has increased the case to be constructed the breakwaters where the water depth is deeper and the wave height is greater. The authors developed a new type of breakwater. This breakwater consists of wave absorbing caisson and sloping top caisson. Through the model experiments, the wave force formula, the reflection coefficient, and the wave overtopping quantity were defined. However, it was not defined the relation between the crown height and the transmission coefficient of this breakwater. When the crown height of the breakwater is higher it can be tranquil. Otherwise, the breakwater width must be extended because of the wave force increased. Then, it is important to define the relation between the crown height of the breakwater and the transmitted wave height and find the appropriately crown height of the breakwater.

In this paper, the authors carried out the experiments for several types of breakwaters by using irregular waves, and defined the formula for the transmission coefficient and the crown height of the breakwater to be required.
\end{abstract}

Key Words : breakwater, reflection and transmission coefficient, crown height

\section{1.はじめに}

港湾の沖合展開に伴い，大水深・高波浪域で防波 堤を建設する機会が増えてきている．この様な背景 のもと，筆者らはコスト縮減が可能な新形式防波堤 として, 直立消波堤と上部斜面堤の長所を組み合わ せた上部斜面消波堤（図-1参照）の開発に取り組ん できた。波力算定式，および，反射率，越波流量に 関しては既報”の通りであるが，今回は上部斜面消 波堤の天端高さを決めるために必要となる波高伝達 率特性に着目した実験を実施した。

防波堤天端高さは，現行の技術基準2)によると， 直立堤の場合は, 朔望平均満潮面 (H.W.L.) 上, 有 義波高 $\left(H_{1 / 3}\right)$ の概ね0.6倍以上，もしくは，特に越 波量を極力低減したい場合には1.25倍以上とされて いる.一方, 上部斜面堤に関しては, H.W.L.+1.0 $H_{1 / 3}$ としたときに, 直立堤の0.6 $H_{1 / 3}$ と波高伝達率が同程 度となることから，1.0H ようである.いずれにしても天端高を高くすること で, 港内静穏度は向上するが, その分, 堤体に作用 する波力も増大するため, 堤体幅が広くなり建設コ ストが増大してしまう。したがって，天端高を適切 に定めることは非常に重要である.今回の実験では, 上部斜面消波堤の波高伝達率を把握することが第一
の目的であるが，他の代表的な構造との相対的な比 較検討を行うため下記の5形式を検討対象とした。
a)直立堤
b) 上部斜面堤
c)直立消波堤
d)上部斜面消波堤
e)消波ブロック被覆堤

また，反射率に関しても，波高伝達率に影響を与え るため合わせて検討を行っている.

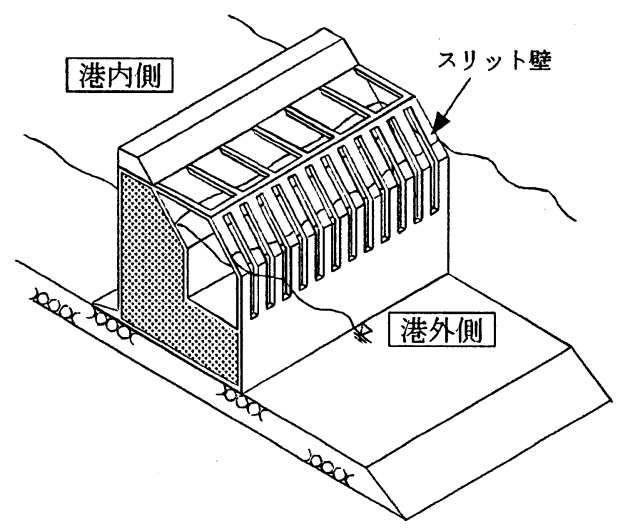

図-1 上部斜面消波堤 


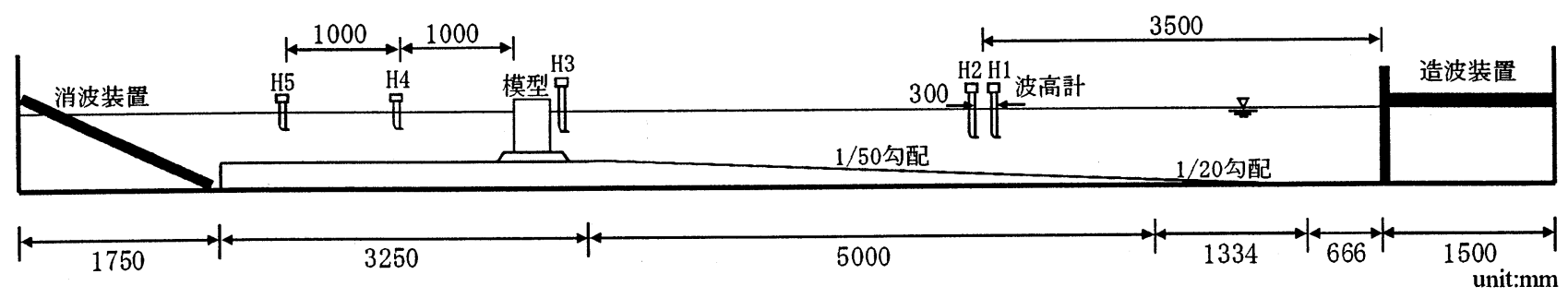

図-2 水路図

\section{2. 実験概要}

\section{（1）実験水路，および堤体模型}

\section{a) 実験水路}

本実験は, 吸収制御式の2次元造波水路(長さ13.5m ×高さ0.8m×幅0.9m）を用いて実施した。水路図を 図-2に示す. 水路内には, 1/50勾配の水路床を設け, 造波装置から7.3mの地点に堤体模型を設置した。波 高計は，造波装置から $3.5 \mathrm{~m}$ 地点にH1，H2を $30 \mathrm{~cm}$ 間 隔で設置し，堤前にH3を設置した。堤体の背後には 1.0m間隔で波高計H4,H5を設置じた。

\section{b) 堤体模型}

堤体模型は，水深-15mに設置される防波堤を想定 し，縮尺1/60でモデル化した。実験対象とした各モ デルの断面図を図-3に示す.

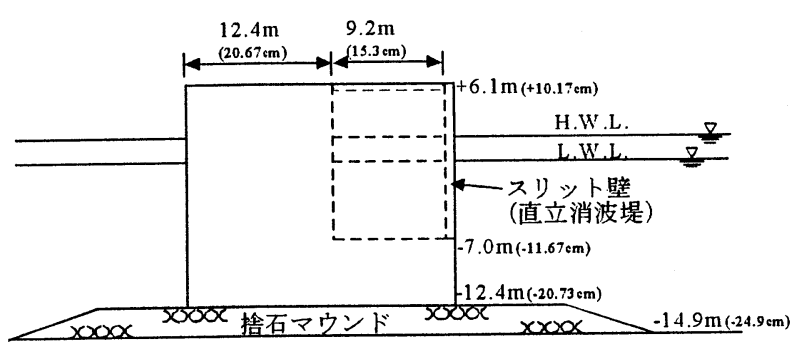

a)直立堤 b)直立消波堤

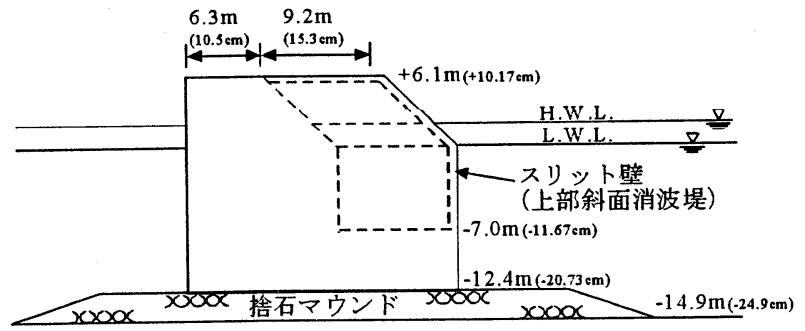

c) 上部斜面堤 d) 上部斜面消波堤

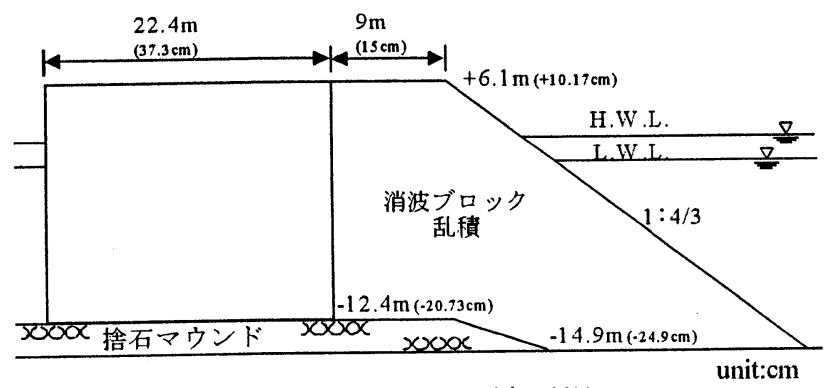

e)消波ブロック被覆堤

図-3 模型断面図
模型の堤体部分はアクリルで製作し，直立消波堤， 上部斜面消波堤のスリット開口率は $30 \%$, 上部斜面堤， 上部斜面消波堤はL.W.L.の水位から 45 度の斜面とし た。消波ブロック被覆堤は，2.55N/個のモルタル製 の消波ブロック（実物で64t型相当）を天端 2 列並び で1:4/3の勾配で乱積みにした。

\section{(2) 実験条件}

表-1に実験条件を示す．実験縮尺は1/60であり， フルード相似則に基づいて実験条件を決定した。実 験波は，不規則波を用いることとし，反射率測定実 験では比較的波高の小さな常時波浪を, 波高伝達率 測定実験では激浪時を対象として作成した。不規則 波のスペクトルはBretschneider-光易型を目標として， 造波開始20.0s後から100～130波に相当する波群を 作成した. 波高伝達率測定実験では, H.W.L., L.W.L. 時の水位に対して, 波高を変化させて, 相対天端高

(防波堤天端高/有義波高) と波高伝達率の関係を把 握することが目的である。そのため，H.W.L.時では 有義波高を2.6〜8.4mまでの10種類, L.W.L.時では有 義波高を3.9〜 7.7mの7種類とした。

\section{表-1 実験条件}

【反射率測定実験】

\begin{tabular}{|c|c|}
\hline \multirow{2}{*}{ 水位 } & L.W. L. \\
\cline { 2 - 2 } & $15.0 \mathrm{~m}(24.9 \mathrm{~cm})$ \\
\hline 周期 & $7.0 \mathrm{~s}(0.9 \mathrm{~s})$ \\
\hline 有義波高 & $\begin{array}{c}2.0,2.4,2.8 \mathrm{~m} \\
\text { (3.3, } 4.0,4.7 \mathrm{~cm})\end{array}$ \\
\hline
\end{tabular}

注）波高はH1，H2地点における分離入射波高の值

【波高伝達率実験】

\begin{tabular}{|c|c|c|}
\hline 実験縮尺 & \multicolumn{2}{|c|}{$1 / 60$} \\
\hline & H. W. L. & L. W. L. \\
\hline 水位 & $17.0 \mathrm{~m}(28.2 \mathrm{~cm})$ & $15.0 \mathrm{~m}(24.9 \mathrm{~cm})$ \\
\hline 周期 & $\begin{array}{l}10.0 \mathrm{~s}(1.29 \mathrm{~s}) \\
14.5 \mathrm{~s}(1.88 \mathrm{~s})\end{array}$ & $\begin{array}{l}10.0 \mathrm{~s}(1.29 \mathrm{~s}) \\
14.5 \mathrm{~s}(1.88 \mathrm{~s})\end{array}$ \\
\hline 有義波高 & $\begin{array}{l}2.6 \sim 8.4 \mathrm{~m}: 10 \text { 種類 } \\
(4.36 \sim 13.94 \mathrm{~cm})\end{array}$ & $\begin{array}{l}3.9 \sim 7.7 \mathrm{~m}: 7 \text { 種類 } \\
(6.42 \sim 12.84 \mathrm{~cm})\end{array}$ \\
\hline
\end{tabular}

注）波高は通過波高検定の堤前 (H3) の値，()は実験值

\section{(3) 実験方法}

実験では，造波装置より不規則波を発生させ，水 路内に設置した5台の波高計H1〜H5を用いて波高デ 一夕を収録する。デー夕の収録は，堤体で反射する 波がH1に到達する造波開始20.0s後から開始した.収 録した波高データを用いて反射率・波高伝達率を以 下に示す方法で算定した。 


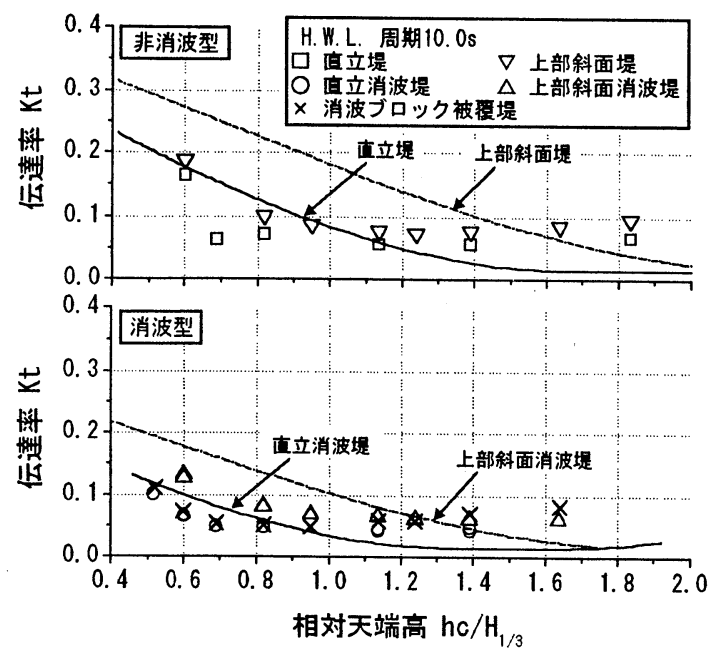

図-4.1 伝達率図（H.W.L. 周期10.0s）

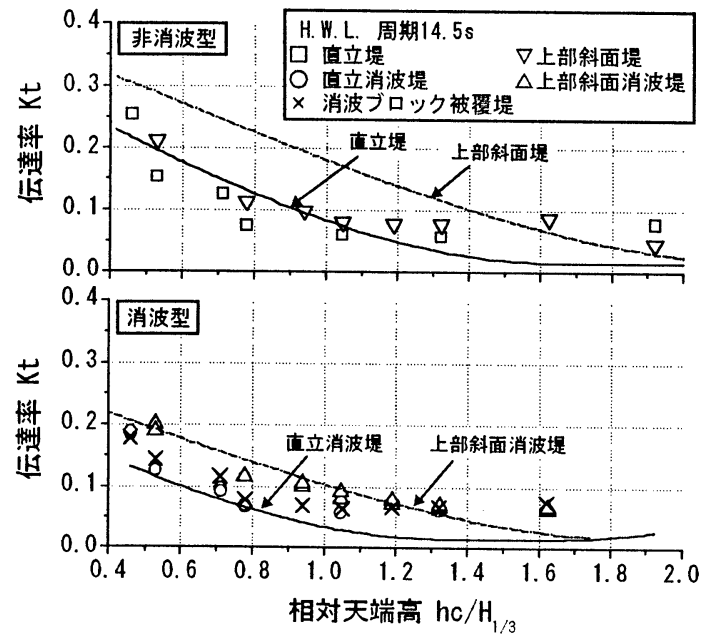

図-4.2 伝達率図（H.W.L. 周期14.5s）

\section{a) 反射率の算定}

波高計H1，H2で収録したデー夕を用いて合田の 入・反射分離法 ${ }^{3}$ で反射率を算定.

\section{b) 波高伝達率の算定}

波高計H4,H5の収録したデータから $H 4_{1 / 3}, H 5_{1 / 3}$ を 求め, この2地点の平均值を伝達波高とし, 通過波高 検定で測定した有義波高 $H_{1 / 3}$ との比から波高伝達率 を算定.

\section{3. 実験結果}

\section{（1）反射率特性}

表-2は，L.W.L.，周期7.0sにおける直立消波堤， 上部斜面消波堤，消波ブロック被覆堤の反射率であ る.その結果, 各構造形式とも反射率は 0.4 以下とな っており, 周期 $7.0 \mathrm{~s}$, 有義波高 $2.0 \sim 3.0 \mathrm{~m}$ 程度の常時 波浪に対して優れた消波性能を有していることがわ かる。また，上部斜面消波堤の反射率は直立消波堤 と同程度であることから，谷本ら ${ }^{4)}$ による直立消波 堤の算定式を用いて上部斜面消波堤の反射率を推定 することが可能である。

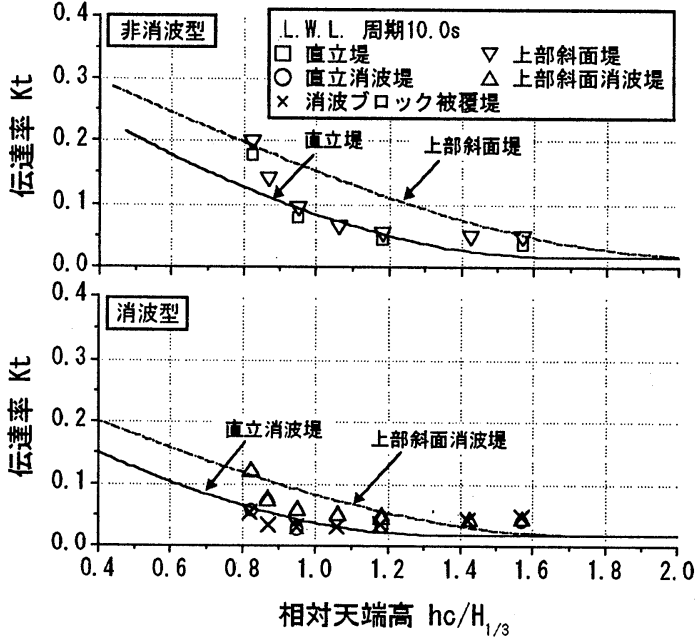

図-4.3 伝達率図（L.W.L. 周期10.0s）

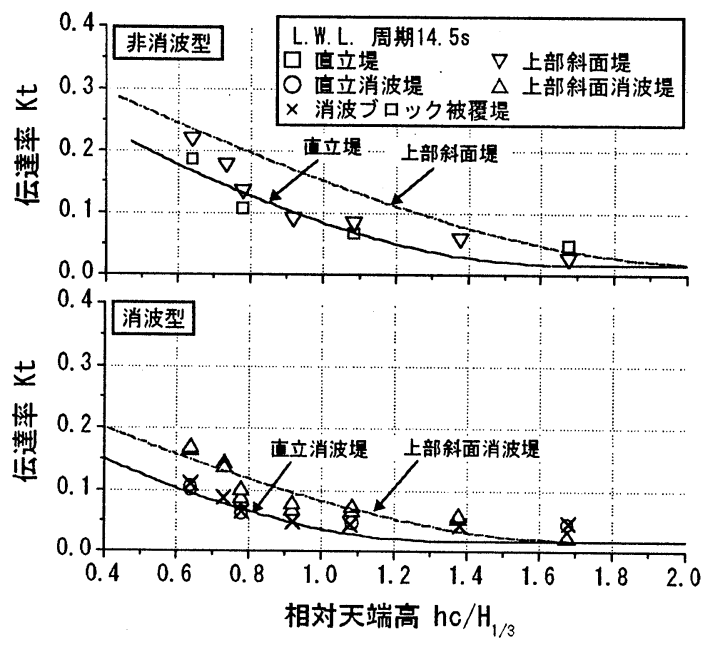

図-4.4 伝達率図 (L.W.L. 周期14.5s)

表-2 各構造形式の反射率

\begin{tabular}{|c|c|c|c|}
\hline & \multicolumn{3}{|c|}{ 有義波高(m) } \\
\cline { 2 - 4 } & 2.0 & 2.4 & 2.8 \\
\hline 直立消波堤 & 0.33 & 0.31 & 0.29 \\
\hline 上部斜面消波堤 & 0.33 & 0.3 & 0.29 \\
\hline 消波ブロック被覆堤 & 0.23 & 0.22 & 0.21 \\
\hline
\end{tabular}

\section{（2）伝達率特性}

\section{a) 各構造形式における伝達率}

図-4.1〜4. 4は,水位と周期別の各構造形式の伝達 率である。横軸は相対天端高 $h c / H_{1 / 3}$ であり，消波機 能の有無によって, 直立堤, 上部斜面堤 (非消波型) と直立消波堤，上部斜面消波堤，消波ブロック被覆 堤（消波型）に分けて示している。その結果，伝達 率は相対天端高に依存し, 水位・周期による差は明 瞭でなかった。構造形式ごとでは，消波型の方が伝 達率は小さくなっている.これは, 消波効果により, 堤前での波高（入射波と反射波の合成波高）が小さ くなり, 越波しにくくなるためである.上部斜面堤, 上部斜面消波堤の伝達率は，斜面で越波が促進され るため, それそれ直立堤, 直立消波堤と比較して若 干大きな值となっている．また，消波ブロック被覆 堤の伝達率は直立消波堤と同等であった。 


\section{b) 伝達率の算定式}

図-4の非消波型の部分に示した実線・点線は，合

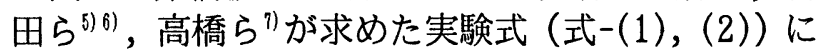
基づいて今回の実験条件から算定した值である. 式 中で用いられている係数 $\alpha$ は, 相対天端高に対して 波高伝達率が減少する比率を表しており，直立堤に 対して合田らは $\alpha=2.2$ 用いている. また， $\beta$ の值 はマウンド上水深 $d$ と水深 $h$ の比で定まり,$d / h$ が小さ い程 (マウンド天端が高い程) $\beta$ の值は小さくなり， 同じ相対天端高における伝達率は大きくなる。これ は，マウンド天端が高い場合，マウンド上の砕波に よって水位が上昇し，越波が増大するためである。

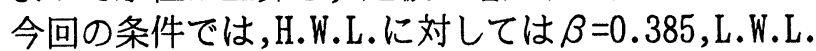
では $\beta=0.381$ となる.

直立堤，上部斜面堤の波高伝達率の実験值と，実 験式から算定した值を比較すると両者は概ね一致し ており，今回の実験対象とした断面に対しても実験 式が適用できることがわかる。 そこで，今回新たに 直立消波堤と上部斜面消波堤に対して実験式の適用 を試みた。図-4の消波型の部分に示した実線・点線 は，直立消波堤と上部斜面消波堤の実験式から算定 した值である. 今回求めた実験式は，係数 $\alpha$ は直立 堤と同じ 2.2 の值を用い, $\beta$ の值をH.W.L.では $\beta$ $=0.705$, L.W.L.では $\beta=0.69$ としている.すなわち, 消波堤による効果を，低マウンドとして越波を減少 させる側の $\beta$ （低マウンドほど $\beta$ が小さくなる）を 用いることで表現している。実験值と実験式から求 めた算定值は良好に一致していることから，直立消 波堤, 上部斜面消波堤の伝達率は, 直立堤, 上部斜 面堤の伝達率の実験式の $\beta$ を修正することで算定で きることがわかった.

$$
\begin{aligned}
& \text { [直立堤 }] \\
& K t=\left\{0.25 \times\left[1-\sin \frac{\pi}{2 \times \alpha}\left(\frac{h c}{H_{1 / 3}}+\beta\right)\right]^{2}+0.01 \times\left(1-\frac{d}{h}\right)^{2}\right\}^{0.5} \\
& : \beta-\alpha<h c / H_{1 / 3}<\alpha-\beta
\end{aligned}
$$

$$
\begin{aligned}
& \text { [上部斜面堤 }] \\
& K t=\left\{\begin{array}{c}
\left.0.25 \times\left[1-\sin \left(\frac{\pi}{4.4} \times\left(\frac{h c}{H_{1 / 3}}+\beta+\beta_{s}\right)\right)\right]^{2}+0.01 \times\left(1-\frac{d}{h}\right)^{2}\right\}^{0.5} \\
: \beta+\beta_{s}-2.2<h c / H_{1 / 3}<2.2-\left(\beta+\beta_{s}\right)
\end{array}\right. \\
& K t=0.1 \times\left(1-\frac{d}{h}\right) \quad: h c / H_{1 / 3}>2.2-\left(\beta+\beta_{s}\right) \\
& \beta_{s}=-0.3 \times\left[\left(h c-2 d_{c}\right) / H_{1 / 3} \tan \theta\right]^{0.5} \\
&
\end{aligned}
$$

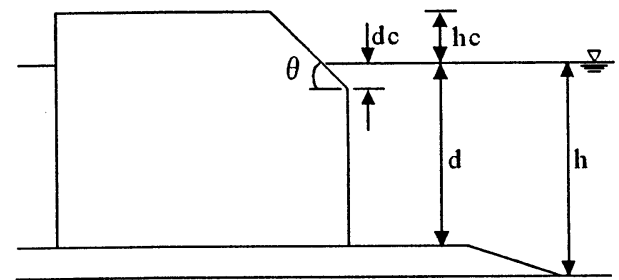

c) 直立消波堤と上部斜面消波堤に対する必要天端高 の検討

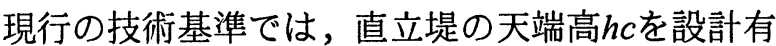
義波高 $H_{1 / 3}$ の0.6倍以上とすることが標準となってい る.そのため，直立消波堤の天端高も，直立堤と同 様に0.6 $H_{1 / 3}$ が用いられることが多い。しかし，今回 の実験結果を用いると, 直立堤の $h c / H_{1 / 3}=0.6$ の伝達 率と同等の值とするためには，直立消波堤の $h c / H_{1 / 3}$ を概ね $h c / H_{1 / 3}=0.4 〜 0.5$ とすればよいことがわかる. また，同様に上部斜面消波堤では $h c / H_{1 / 3}=0.6$ 程度で 直立堤と同等の伝達率となる。このように，直立堤 の伝達率と同等にする条件では，消波構造とするこ とで防波堤天端高を低くすることが可能となり，コ ス卜低滅に結びつくものと思われる。

\section{4.まとめ}

各種ケーソン式防波堤の反射率・伝達率特性を明 らかにするため不規則波実験を行い，直立消波堤と 上部斜面消波堤の波高伝達率の算定式を求めた。ま た，この算定式を用いて必要天端高についても考察 を加えた. 以下に，今回の実験から得られた結論を 示す.

1) 今回対象とした断面では，常時波浪（周期7.0s， 有義波高2.0～3.0m)における消波型防波堤の反射 率はいずれも0.4以下であった.また，上部斜面消 波堤の反射率は，直立消波堤の值と同程度で，谷 本らの直立消波堤の反射率算定式で推定すること ができる。

2) 同じ波浪条件で比較した場合，直立消波堤・上部 斜面消波堤は，遊水室の貯水効果と反射波低減に よる堤前波高の低下のため, 直立堤・上部斜面堤 よりも波高伝達率を低く抑えることができる.

3）直立堤 ·上部斜面堤 - 直立消波堤 $\cdot$ 上部斜面消波 堤の伝達率を比較した結果, 直立堤における合田 らの実験式を修正することで, 直立消波堤, 上部 斜面消波堤の伝達率を算定できる.

4)波高伝達率に関して，直立消波堤では $h c / H_{1 / 3}=0.4$ $\sim 0.5$, 上部斜面消波堤では $h c / H_{1 / 3}=0.6$ 程度とする ことで直立堤の $h c / H_{1 / 3}=0.6$ における伝達率と同等 の值となることがわかった。

\section{参考文献}

1) 本田秀樹，塩崎禎郎，堀内 博，辻岡和男：高波浪域 向け消波型ケーソンの開発，海洋開発論文集，Vol.16, pp. $245-250,2000$

2）（社）日本港湾協会 : 港湾の施設の技術上の基準・ 同解説, 1999 .

…（2）3）合田良実，鈴木康正，岸良安治，菊池治：不規則波実 験における入・反射の分離推定法, 港湾技術研究所資 料 No. 248, pp. $1-24,1976$.

4) 谷本勝利, 吉本靖俊: 直立消波ケーソンの反射率に関 する理論および実験的研究, 港湾技術研究所報告 第21 巻, 第3号, 1982.

5) 合田良実, 竹田英章: 越波による防波堤背後への波高 伝達率, 第13回海岸工学講演会講演集, pp. 87-92, 1966.

6) 合田良実, 鈴木康正, 岸良安治: 不規則波浪実験とそ の特性について, 第21回海岸工学講演会講演集, pp. 237-242, 1974 .

7）高橋重雄, 下迫健一郎: 防波堤の耐波設計, 港湾工学 専門技術者水エコース研修テキスト，1996. 